\title{
Supply risk management: A case study of halal food industry in Malaysia
}

\author{
Fadhlur Rahim Azmi ${ }^{a}$, Haslinda Musa ${ }^{a^{*}}$, Boon Cheong Chew and Indira Priyadarsini Jagiripu ${ }^{\mathrm{b}}$
}

${ }^{a}$ Faculty of Technology Management and Technopreneurship, Universiti Teknikal Malaysia Melaka, Durian Tunggal, Malaysia ${ }^{b}$ School of Management Studies, University of Hyderabad, India

\section{H R O N I C L E}

\begin{tabular}{l}
\hline Article history: \\
Received October 2, 2020 \\
Received in revised format \\
November, 10, 2020 \\
Accepted January 72021 \\
Available online \\
January 72021 \\
\hline Keywords: \\
Agency theory \\
Supply risk management \\
Halal supply chain \\
Mitigation strategy \\
Exploratory factor analysis
\end{tabular}

\section{A B S T R A C T}

\begin{abstract}
The purpose of this study is to identify the types of halal food supply risks, types of mitigation strategies for the upstream supply chain and to examine the relationship between halal supply risk and mitigation strategy efforts using the lens of the agency theory. Exploratory factor analysis (EFA) is used to validate the variables of the study and regression is performed to analyze the relationship of halal food supply risk and mitigation strategy. It is identified that halal food supply risk (agency uncertainties) consists of quality risk, delivery risk, and price/cost risk. The mitigation strategy efforts consist of behavior-based management, buffer-based management, and traceability-based management. Results indicate that halal food supply risk significantly increase mitigation strategy efforts of firms. However, price $\&$ cost risk does not significantly increase behavior-based management. Practical implications include suggesting the firms to invest more in buffer-oriented so as to mitigate the agency uncertainties.
\end{abstract}

(C) 2021 by the authors; license Growing Science, Canada.

\section{Introduction}

Securing a source of the product being supplied to the food manufacturer is very important in halal supply management. The relationship between buyer and supplier should be integrated so as to implement strategic management for producing halal products. However, there is a lack of empirical study on the "types of halal supply risks" and "mitigation strategy" in order to manage risk consequences in the halal food supply chain (HFSC). Risk in halal food transportation (Yaacob et al., 2018), identifying the risk elements related to the HFSC (Khan et al., 2019) and supplier management in the HFSC (Fujiwara \& Ismail, 2018) are few of them. From the context of the recent study related to risk management, it is identified that there is no further examination of the types of halal food supply risk and the risk management strategy. There is a need to have an in-depth supply risk management (SRM) study to manage halal food supply risk that can lead to adverse risk consequences in HFSC. Thus, the purposes of the study to identify the types of halal food supply risks and types of mitigation strategies. Furthermore, the study examines the relationships between halal supply risk and mitigation strategy efforts performed by food manufacturers.

\section{Literature review}

This section is an overview of the literature in area of SRM and development of the hypotheses of the study by utilizing established theories. The study adopted existing literature in SRM to develop the hypothesis due to the insufficient literature on halal SRM.

\subsection{Source of supply risk}

Cheng et al., (2012) defined supply risk concerning the likelihood related to the inbound supply from the supplier failures or an inconsistent supply market, for which the results bring a lack of ability the principal to fulfill the demand or cause a threat (life and safety) to the consumer. The study of SRM is more concentrated on upstream risks so as to identify quality risk, price and cost risk and delivery risk (Diabat et al., 2012; Gouda \& Saranga, 2018; Manuj \& Mentzer, 2008; Zsidisin et al., 2016). This study adopted the classification of supply risk as follows:

* Corresponding author

E-mail address: haslindamusa@utem.edu.my (H. Musa)

(C) 2021 by the authors; licensee Growing Science. doi: $10.5267 /$ j.uscm.2021.1.001 
a) Price \& cost risk

b) Quality risk

c) Delivery risk

\subsection{Supply risk and mitigation strategies}

The agency theory is spotted when the issues that come to pass from one party addressed as a principal delegate the works to another party addressed as an agent (Eisenhardt, 1989). Various studies applied this theory to understand how both parties in the supply chain structure are managing risks (Fayezi et al., 2012). The study considers the food manufacturing company which is halal based as principal and the supplier as agent. The application of agency theory, in case of large number of risks associated with the halal food manufacturer, recommends that the firm should embrace efforts that diminish the likelihood and effect of an adverse function on the association. As per the agency theory, appropriate risk reduction techniques are clustered as behavior-based management efforts or buffer-oriented efforts to protect the principal from destructive events (Fayezi et al., 2019; Gandhi et al., 2012; Shafiq et al., 2017; Zsidisin \& Ellram, 2003). Behavior-oriented efforts focus on those activities or tasks that give to a decrease in supply-side risk. As the buffer-oriented efforts are a greater amount of a result-based approach firms utilize buffers to diminish the impact of risk events. Moreover, the study stressed that the traceability technique is important in halal management assurance in order to secure the halalness of the products.

The measurement and process of operating activities proactively (prevent) utilize by behavior-oriented efforts that will lead to a decrease in supply-side risks (Cheng et al., 2012). As mentioned by (Gouda \& Saranga, 2018), likelihood of risk events in supply chain activities can be reduced by utilizing preventive risk mitigation efforts. This effort needs human/monetary input information sources to improve the processes and decrease the possibility of risk events. (Cheng et al., 2012; Gandhi et al., 2012; Shafiq et al., 2017). The supplier's behavior is evaluated so as to give an impact on the buyer's outcomes (Whipple \& Roh, 2010; Zsidisin \& Ellram, 2003). The initiatives of this technique are implementation of the quality management program, supplier certification, supplier development and supplier quality audit (Spekman \& Davis, 2004; Zsidisin \& Ellram, 2003; Zu \& Kaynak, 2012). The study proposes that agency uncertainties (halal supply risks) can be managed (mitigate) through the adoption of the behavior-based management technique which promotes supplier halal information, halal integrity (trust), and assurance quality, so as to reduce the likelihood of partner opportunism. This technique follows the agency theory's gauge that the principals will draw on behavior-based management techniques when the goal, risk, and information-sharing conditions in their relationships with agents are favorable (Eisenhardt, 1989). Therefore, the study proposes the following hypotheses:

\section{$\boldsymbol{H}_{\boldsymbol{I}}$ : Price \& cost risk significantly increases behavior-based management efforts. \\ $\boldsymbol{H}_{2}:$ : Quality risk significantly increases behavior-based management efforts. \\ $\mathrm{H}_{3}$ : Delivery risk significantly increases behavior-based management efforts.}

Buffer-oriented efforts which are reactive includes keeping the safety stock, multiple supply sources and requiring the suppliers to hold inventory (Cheng et al., 2012). These approaches aim to reduce adverse effect of the supplier's activities (Fayezi et al., 2019). Buffer oriented approaches are more of outcome-based management and firms utilize buffers to lessen the impact of the risk events (Gandhi et al., 2012). Ho et al., (2015) and Ivanov et al., (2017) stated that the principal can utilize multiple sources of supply, maintaining safety stock, and multiples modes of transportation for the same items as a buffer to address supply risk. This strategy limits the risk which occurs due to the network's supply chain and scaffold activities that length the limits of the firm to accomplice supply chain partners in the process of diminishing the risk (Gouda \& Saranga, 2018). This is advantage for principals when one supplier fails to deliver as per contract, other sources remain to neutralize the supply gaps. In this context, the study proposes that buffer-based management mechanisms are abled better to assist halal food manufactures in mitigating the adverse consequences of agent imperfection, without substantive intervention into agent operations. It promotes multiple halal supply sources, accessibility of halal transportation, and certified facilities of the halal supplier. Therefore, the following hypotheses have been formulated:

$\mathbf{H}_{4}$ : Price \& cost risk significantly increases buffer-based management efforts.

H5 $_{5}$ : Quality risk significantly increases buffer-based management efforts.

$\mathbf{H}_{6}$ : Delivery risk significantly increases buffer-based management efforts.

Ab Talib et al., (2015) explored and concluded that traceability is one of the halal supply chain's critical success factors. Low data integrity for halal products and lack of traceability system poses a threat to the effective management of the halal supply chain (Khan et al., 2018). Application of traceability in halal context is at a new stage due to its infancy of large scale of halal products (Mat Aris \& Soon, 2014; Shafii \& Khadijah, 2012). According to Khan et al., (2018), halal traceability aims for transparency of halal production that leads to an increase in consumer trust in the final products. Established traceability practices in halal management can mitigate cross-contamination risk and reduce cost, in the longer run (Abd Rahman et al., 2017; Mohamed et al., 2016; Zhao et al., 2018). The advantages of traceability can channel information related to halal standards allow food manufacturers or consumers to verify halal products and secure the specification of the halal requirement (Shafii \& Khadijah, 2012). By obtaining information from halal authority, this allows the stakeholders to get information about the product (Ab Talib \& Chin, 2018) such as the name of firms, manufacturer of the products whereas a food manufacturer can trace the supplier who has the halal certification. Implementation of halal food traceability system in the upstream supply chain can be considered effective by monitoring systems and inventory 
management systems. Raw material should be good, clean, permitted, legal nutrition food and be slaughtered according to Sharia law (Ali et al., 2017; Mohamed et al., 2016). For inbound logistics, if needed, Samak should be done to certain trucks or containers (Fujiwara \& Ismail, 2018; Mohamed et al., 2016; Supian, 2018). For production-level, using halal equipment and worker practice the concept of hygiene is implemented as permitted by Sharia law (Mohamed et al., 2016). Being traceability-oriented can be a preventive approach to reduce supply risk. It promotes authenticity of traceability information on halal suppliers (Duan et al., 2017) the ability to trace the quality of the halal product, providing halal awareness to the supplier, and the ability to identify whether the product was dispatched or stored accordingly based on halal standards (Abd Rahman et al., 2017). Therefore, the following hypotheses have been formulated:

$\begin{array}{lll}\mathbf{H}_{7} & \text { : } & \text { Price \& cost risk significantly increases traceability-based management efforts. } \\ \mathbf{H}_{8} & \text { : } & \text { Quality risk significantly increases traceability-based management efforts. } \\ \mathbf{H}_{9} & \text { : } & \text { Delivery risk significantly increases traceability-based management efforts. }\end{array}$

\section{Methods}

The element of the investigation depends on a positivist model as the study applies a deductive methodology. It has derived hypotheses from theories after reviewing the literature thereby confirming the hypotheses. As it is often associated with a deductive approach, survey strategy is applied for this study. This study collected large amount of data to address the halal food manufacturers in Malaysia. Substantial of data is obtained from Jabatan Kemajuan Islam Malaysia (JAKIM) halal directory website. A set of questionnaires are utilized as an instrument for the survey approach in order to obtain input for data measurements from the halal food manufacturing company.

\subsection{Sampling design}

The study utilized a convenience sampling technique to collect data information from halal food manufacturer firms. An appropriate way for this study to collect a sample by visiting the JAKIM halal directory website to acquire data with variables like the type of industry, name of firm, e-mail address, the person in charge, etc. To address the research objectives, the study utilizes the input data from questionnaires. A total of 111 halal food firms took part in the survey.

\subsection{Questionnaire development}

Questionnaire is the instrument used for survey method so as to obtain information for data measurements from the halal food manufacturing company. A quality questionnaire should be straight to the point, simple, and readable (Frazer \& Lawley, 2001). According to Lynn, (1986), the development of a questionnaire involves two processes; content development stage and judgment stage. At the content development stage, the study constructs the content domain from literature reading, generating the appropriate items and structuring the instrument. The content domain can be identified by reviewing the literature on the related topic of the study, interviewing related respondents or performing a focus group study (Zamanzadeh et al., 2015). The literature of the halal study is very limited. Therefore, the study adopted the content domain from the previous study related to SRM. Based on section 2, it is identified that halal SRM consists of a type of supply risk (quality, price and costs, and delivery risk) and risk mitigation strategy (behavior-based management, buffer-based management, and traceability-based management). In the judgment stage, the study invited a specific group of experts (based on area expertise) for a pre-test to confirm the proposed item in the questionnaire. The expert will calculate the degree of relevance item for each variable to determine the suitability of content domains. The development of an instrument will be confirmed by the experts in order to ensure the domains are adequacy with the particular concept of interest (Nunnally \& Bernstein, 1994). Exploratory factor analysis (EFA) was used to validate the scale of the questionnaire. This technique was recommended by (Hair et al., 2019). The study performed EFA by utilizing seven steps compiled by Moretti et al., (2019). Appendix A shows that the final questionnaire for the study.

\subsection{Exploratory factor analysis (EFA)}

EFA helps researchers for exploring the main elements to develop a model or a theory, represented by a set of items derived from a large set of latent constructs (Henson \& Roberts, 2006; Pett et al., 2003), and it's used to validate the scale of the variables (Hair et al., 2019). EFA process is to derive a smaller set of underlying factors from a large number of variables that can be categorized and the essential information in the variables be summarized (Dobni, 2008).

Table 1

\begin{tabular}{clll}
\multicolumn{2}{l}{ Steps for the application of EFA } & & \\
\hline Steps & Description & Steps & Description \\
\hline 1 & $\begin{array}{l}\text { Extraction method: PCA- principal component analysis } \\
\text { Rotation method: Varimax orthogonal }\end{array}$ & 4 & Anti-image correlation: $>0.50$ \\
2 & Kaiser-Meyer-Olkin (KMO): $>0.60$ & 5 & Communalities values: $>0.50$ \\
3 & Bartlett's test: Correlations among the variables are valid. & 6 & Total variance explain: at least $60 \%$ of variances. Eigenvalue: $>1.0$ \\
\hline
\end{tabular}


Table 1 presents seven steps in conducting EFA. The 10-point interval scale (1- strongly disagree to 10- strongly agree) has been used in the operating measurement for each item. This scale is more efficient in the measurement model because of its extensive choice and higher independence (Awang et al., 2016).

\subsection{Regression analysis}

Regression analysis is used to identify the correlations between two or more variables having cause and effect relations. Regression also can utilize to prediction of model by utilizing the relation of the variables (Uyanık \& Güler, 2013). Thus, it can serve as an analysis tool to measures relationships and for testing the hypothesis of the study. This study applies regression analysis for examining the relationships between halal supply risk and mitigation strategy in order to investigate the effectiveness of halal SRM.

\section{Results}

\subsection{Analysis of halal supply risk factors}

Table 2 shows the results of EFA for halal supply risk factors. As recommended by (Hair et al., 2010) the EFA is established when the value of KMO-MSA is higher than the threshold value of 0.7. In this case, the EFA for halal supply risks construct $($ KMO-MSA $=0.894)$ is satisfied as they meet the EFA requirement. In addition, the Bartlett test (1145.145) for all constructs shows a significant ( $\mathrm{p}$-value: $0.00<0.05$ ) which says the data is valid to be tested with EFA. Through the measure of sampling adequacy index, a better analysis of each variable sufficiency to the study of EFA is conducted. As suggested by (Cleff, 2019), it is suitable for values from the main diagonal higher than 0.5 . The elements from the main diagonal are above 0.5 , many of them exceeding threshold of 0.7 . Anti-image correlation coefficients indicate that the factor analysis is appropriate. According to Hair et al. (2009), the acceptable threshold for communalities value is 0.50. Two items in halal supply risk construct were identified having a poor value of communalities which are QR5 $=0.255$ and DR7 $=0.237$. Nonetheless, the analysis is proceeded to the following steps to confirm the results. It is possible to generate a factorial model, having met all of these previous criteria. Three components of the type of halal supply risks (agency uncertainties) explain $63.762 \%$ of data variance. Meanwhile, those components had had eigenvalues above 1.0 which are components 1 , 2 , and 3 presented values of $7.468,2.448$, and 1.562 , respectively. It means that more than half of the total variance has been explained. In addition, the three components were yielded after executing with principal component analysis. Hence, the model generated can be considered valid.

Table 2

Analysis of EFA for halal supply risk factors

\begin{tabular}{lcll}
\hline Analysis of statistic & Value & Analysis of statistic & \\
\hline No. of items & 18 & Anti-image correlation coefficients & Value \\
KMO-MSA & 0.894 & Eigenvalue of factor 1 (quality risk) & 7.468 \\
Bartlett's test & 1145.145 & Eigenvalue of factor 2 (delivery risk) & \\
Df & 153 & Eigenvalue of factor 3 (price \& cost risk) & 2.448 \\
Sig. $p$ value & 0.00 & \% of Cumulative Variance for three factors & 1.562 \\
\hline
\end{tabular}

Meanwhile, Table 3 shows the rotated component matrix results after performing the varimax rotation. The total item to be tested under the halal supply risk construct is 18 .

Table 3

Rotated Component Matrix for halal supply risk

\begin{tabular}{|c|c|c|c|}
\hline & \multicolumn{3}{|c|}{ Component } \\
\hline & 1 & 2 & 3 \\
\hline PR1 & & & .861 \\
\hline PR2 & & & .797 \\
\hline PR3 & & & .777 \\
\hline QR1 & .819 & & \\
\hline QR2 & .713 & & \\
\hline QR3 & .745 & & \\
\hline QR4 & .791 & & \\
\hline QR5 & Deleted & & \\
\hline QR6 & .755 & & \\
\hline QR7 & .745 & & \\
\hline QR8 & .762 & & \\
\hline DR1 & & .793 & \\
\hline DR2 & & .752 & \\
\hline DR3 & & .712 & \\
\hline DR4 & & .813 & \\
\hline DR5 & & .801 & \\
\hline DR6 & & .786 & \\
\hline DR7 & & Deleted & \\
\hline
\end{tabular}

PR: Price \& cost risk QR: Quality risk DR: Delivery risk 
The first component is about Quality Risks (QR) followed by Delivery Risks (DR) and Price and Cost Risks (PR). In the first and second components, two items (QR5 and DR7) are deleted from the analysis since they carry factor loading below 0.5 . Meanwhile, all items under component three are maintained since the range value of factor loading is between 0.777 and 0.861 .

\subsection{Analysis of mitigation strategy factors}

Table 4 shows the results of EFA for mitigation strategy factors. The EFA is established when the value of KMO-MSA is higher than the threshold value of 0.7 as recommended by (Hair et al., 2010). In this case, the EFA for mitigation strategies construct $(\mathrm{KMO}-\mathrm{MSA}=0.911)$ is satisfied as they meet the EFA requirement. In addition, the Bartlett test for all constructs shows a significant ( $p$-value: $0.00<0.05$ ) in which the data is valid to be tested with EFA. The study of EFA through the measure of sampling adequacy index is conducted using a higher accurate analysis for each variable adequacy. This index is suitable for those values from the main diagonal higher than 0.5 and is presented in anti-image correlation matrix, as recommended by (Cleff, 2019). With most of the elements exceeding the threshold of 0.8 , all the elements from the main diagonal are above 0.5. According to Hair et al. (2009), the acceptable threshold for communalities value is 0.50 . One item in the mitigation strategy construct is identified as having a poor value of communalities which is BBM3=0.171. Nonetheless, the analysis is proceeded to the following steps to confirm the results. Three components of the mitigation strategy explain $61.077 \%$ of data variance. Meanwhile, those components had had eigenvalues above 1.0 which are components 1,2 , and 3 presented values of $8.761,2.229$, and 1.836 , respectively. It means that more than half of the total variance has been explained. In addition, the three components were yielded after executing with principal component analysis. So, the model generated can be considered valid.

\section{Table 4}

Analysis of EFA for mitigation strategy factors

\begin{tabular}{lcll}
\hline Analysis of statistic & Value & Analysis of statistic & \\
\hline No. of items & 21 & Anti-image correlation coefficients & Value \\
KMO-MSA & 0.911 & Eigenvalue of factor 1 (buffer-based management) & Exceeding 0.80 \\
Bartlett's test & 1283.510 & Eigenvalue of factor 2 (behavior-based management) & 2.761 \\
Df & 210 & Eigenvalue of factor 3 (traceability-based management) & \\
Sig. $p$ value & 0.00 & $\%$ of Cumulative Variance for three factors & 1.836 \\
\hline
\end{tabular}

Meanwhile, table 5 shows the rotated component matrix results after performing the varimax rotation. The total item to be tested under the mitigation strategy construct is 21 . The first component is about Buffer-based Management (BFM) followed by Behavior-based Management (BBM) and Traceability-based Management (TBM). In the second component, one item (BBM3) is deleted from the analysis since the carry factor loading below 0.5. Meanwhile, all items under the rest components are maintained since the range value of factor loading is over 0.6 .

Table 5

$\underline{\text { Rotated Component Matrix for mitigation strategy }}$

\begin{tabular}{|c|c|c|c|c|c|c|c|c|c|c|c|}
\hline & \multicolumn{3}{|c|}{ Component } & & \multicolumn{3}{|c|}{ Component } & & \multicolumn{3}{|c|}{ Component } \\
\hline & 1 & 2 & 3 & & 1 & 2 & 3 & & 1 & 2 & 3 \\
\hline BBM1 & & 0.743 & & BFM1 & 0.752 & & & TBM1 & & & 0.78 \\
\hline BBM2 & & 0.732 & & BFM2 & 0.758 & & & TBM2 & & & 0.739 \\
\hline BBM3 & & Deleted & & BFM3 & 0.723 & & & TBM3 & & & 0.711 \\
\hline BBM4 & & 0.714 & & BFM4 & 0.763 & & & TBM4 & & & 0.765 \\
\hline BBM5 & & 0.76 & & BFM5 & 0.722 & & & TBM5 & & & 0.779 \\
\hline BBM6 & & 0.733 & & BFM6 & 0.696 & & & TBM6 & & & 0.698 \\
\hline BBM7 & & 0.786 & & BFM7 & 0.724 & & & & & & \\
\hline BBM8 & & 0.643 & & & & & & & & & \\
\hline
\end{tabular}

\subsection{Reliability test (Cronbach's Alpha: $\alpha$ )}

Internal reliability tests were calculated to obtain $\alpha$ value of the variables in the questionnaire. Table 6 presents the reliability results for halal supply risk and mitigation strategy. All constructs are satisfied since the $\alpha$ value is higher than 0.6 (Hair et al., 2009).

\section{Table 6}

Internal reliability analysis

\begin{tabular}{lcc}
\hline Construct & No. of Items & $\alpha$ \\
\hline Halal supply risk & 16 & 20 \\
Mitigation strategy & 0.921 \\
\hline
\end{tabular}

\subsection{Hypotheses testing}

Table 7 illustrates the results of multiple regression analysis. The $\mathrm{R}^{2}$ for this model revealed 0.341 , which implies that $34.1 \%$ of the variance in the behavior-based management can be foreseen from the grouping of halal supply risk factors. This 
analysis showed quality risk $(b=0.379, p=0.000)$ significantly increases behavior-based management efforts. Delivery risk $(b=0.190, p=0.041)$ also shows significant increase in behavior-based management efforts. However, price and cost risk do not significantly show an increase in behavior-based management efforts. Therefore, $\mathrm{H} 2$ and $\mathrm{H} 3$ are supported by the analysis.

Table 7

Halal supply risk and behavior-based management efforts

\begin{tabular}{|c|c|c|c|c|c|c|}
\hline Predictors & Constant & $b$ & $F$ & $t$ & $p$ & $\mathrm{R}^{2}$ \\
\hline Price and cost risk & \multirow{3}{*}{1.753} & 0.138 & \multirow{3}{*}{18.484} & 1.482 & 0.141 & \\
\hline Quality risk & & 0.379 & & 3.918 & $0.000 * *$ & 0.341 \\
\hline Delivery risk & & 0.190 & & 2.068 & $0.041 *$ & \\
\hline
\end{tabular}

Dependent variable: Behavior-based management

sig. level at $<0.05^{*}$

sig. level at $<0.01 * *$

$\mathrm{N}=111$

Table 8 shows $\mathrm{R}^{2}$ for this model revealed 0.322 , which implies that $32.2 \%$ of the variance in the buffer-based management can be foreseen from the grouping of halal supply risk factors. This analysis showed price and $\operatorname{cost}$ risk $(b=0.216, p=0.024)$, quality risk $(b=0.256, p=0.010)$, and delivery risk $(b=0.235, p=0.013)$ significantly increase buffer-based management efforts. Therefore, H4, H5, and $\mathrm{H} 6$ are supported by the analysis.

Table 8

Halal supply risk and buffer-based management efforts

\begin{tabular}{lccccc}
\hline Predictors & Constant & $b$ & $F$ & $p$ & \multicolumn{2}{c}{$\mathrm{R}^{2}$} \\
\hline Price and cost risk & & 0.216 & & 2.296 & $0.024^{*}$ \\
Quality risk & 1.677 & 0.256 & 16.950 & 2.605 & $0.010^{*}$ \\
Delivery risk & & 0.235 & & 0.322 & 2.528 \\
\hline
\end{tabular}

Dependent variable: Buffer-based management

*sig. level at $<0.05$

$N=111$

Table 9 shows $\mathrm{R}^{2}$ for this model revealed 0.388 , which implies that $38.8 \%$ of the variance in the traceability-based management can be foreseen from the grouping of halal supply risk factors. This analysis showed price and cost risk $(b=0.200, p=0.027)$, quality risk $(b=0.287, p=0.003)$, and delivery risk $(b=0.287, p=0.012)$ significantly increase traceability-based management efforts. Therefore, $\mathrm{H} 7, \mathrm{H} 8$, and $\mathrm{H} 9$ are supported by the analysis.

Table 9. Halal supply risk and traceability-based management efforts

\begin{tabular}{lccccc}
\hline Predictors & Constant & $b$ & $F$ & $t$ & $p$ \\
\hline Price and cost risk & & 0.200 & & 2.239 & $0.027^{*}$ \\
Quality risk & 1.212 & 0.287 & 22.589 & 3.073 & $0.003^{* *}$ \\
Delivery risk & & 0.287 & & 0.388 & 3.239 \\
\hline
\end{tabular}

Dependent variable: Traceability-based management

*sig. level at $<0.05$

$* *$ sig. level at $<0.01$

$N=111$

\section{Discussion}

\subsection{Type of halal supply risk and mitigation strategy efforts}

The results establish that halal food supply risk (agency uncertainties) consists of quality risk, price \& cost risk, and delivery risk. According to Srinivasan et al., (2011), the firm relies on the quality of suppliers in order to secure high quality of products. The firm may face potential risks like the quality problem with materials delivered not meeting the halal standards, products being contaminated by unclean things or haram source (Handayani et al., 2019; Tieman, 2019), and containing the forbidden or dirty component in the ingredients (Hosseini et al., 2019). A crucial issue in supply chain management is managing a supplier who is involved particularly with the raw materials cost and the primary products cost (Yoon et al., 2017). It is related to product price volatility, products recall by the supplier, procurement cost, and other sources of tangible costs caused by the supplier (Alikhani et al., 2019). Additionally, global market competition may lead the firms to face the risk of price volatility (Ghadge et al., 2017). According to Radzi et al., (2017), Japanese food companies are being exposed to the price volatility of raw materials, and the price imported is subjected to foreign exchange. Khan et al., (2019) mentioned, raw materials of halal may increase the value of procurement thereby affecting the performance of supply chain activity. Another type of supply risk which should be taken into account is the delivery risk in the supply chain. According to Supian (2018), there is a potential for cross-contamination when a halal substance comes into contact with the non-halal product. The halal product can become haram if the contact which caused haram is a contact of previous delivery by the same transport. Another potential risk faced by food manufacturer is when the suppliers may fail to segregate allocation for halal products, poor packaging, and preservation (Rathore et al., 2017), and goods are not in good condition after being 
delivered from the suppliers (Kristina \& Wijaya, 2017). Meanwhile, the results establish mitigation strategy efforts in halal SRM which consists of buffer-based management, behavior-based management, and traceability-based management. As stated by agency theory, risk can be reduced by utilizing behavior-based management efforts and buffer-oriented methods to protect the principal from destructive events (Fayezi et al., 2019; Gandhi et al., 2012; Shafiq et al., 2017; Zsidisin \& Ellram, 2003). The adoption of both techniques can be utilized in halal management. The results confirmed through a survey of the study and analysis of EFA. A behavior-based management effort focuses on those processes that lead to a reduction in supply risks. Agency uncertainties (halal supply risks) can be mitigated through the adoption of the behavior-based management technique that promotes supplier halal information, halal integrity (trust), and assurance quality, so as to reduce the likelihood of partner opportunism. According to Fayezi et al., (2019), the agility of enterprises can be developed through this technique such as supplier/buyer engagement (supplier development quality program, and buyer relationship management). Buffer-oriented efforts are outcome-based techniques therefore firms utilize buffers to minimize the consequence of the risks in the supply chain. It promotes multiple halal supply sources, accessibility of halal transportation, and certified facilities of the halal supplier. The principal can utilize multiple sources of supply, maintaining safety stock, and multiples modes of transportation for the same items as a buffer to address supply risk (Ho et al., 2015; Ivanov et al., 2017). Fayezi et al., (2019) mention, agility can be achieved through improving the capability of enterprises, by developing management buffers to mitigate the adverse effects of agency uncertainties centered. Moreover, the study confirms the traceability technique is important in halal management assurance in order to secure the halalness of the products. Establishment traceability practices in halal management can mitigate cross-contamination risk and reduce cost, in the longer run (Abd Rahman et al., 2017; Mohamed et al., 2016; Zailani et al., 2010; Zhao et al., 2018). Being traceabilityoriented can be a preventive approach to reduce supply risk. It promotes authenticity of traceability information on halal suppliers (Duan et al., 2017), the ability to trace the quality of the halal product, provides halal awareness to the supplier, and the ability to identify whether the product was dispatched or stored accordingly based on halal standards (Abd Rahman et al., 2017).

\subsection{Relationship between halal food supply risk and mitigation strategy}

Findings have indicated that quality risks and delivery risks significantly increase behavior-based management efforts. Quality of products (raw material) and delivery is a crucial issue on the supply-side to ensure that the final products meet the quality of the marketplace (Prakash et al., 2017). According to Fayezi et al., (2019), behavior-based management effort enables to ensure the agent to meet the quality requirement and improve the agent's ability. For instance, the firms take the initiative to implement a halal quality management program with their suppliers to ensure the quality of material supplied meets the halal standards and delivered in good condition. However, the results indicated price and cost risk did not significantly increase behavior-based management. The firm cannot adopt this effort to mitigate this type of risk due to the uncontrollable commodity prices. The significant increase in the costs of major ingredients in food and beverage manufacturing can be because of the inconsistencies in the global agricultural commodity prices (Bellmann \& Hepburn, 2017). Meanwhile, the results showed price/cost risk, quality risk, and delivery risks significantly increase buffer-based management efforts. This analysis indicated the more increase in halal supply risk, the more agencies will increase their buffer-oriented efforts. The agency will utilize multiple sources of supply, maintaining safety stock, and multiples modes of transportation for the same items as a buffer to address supply risk (Ho et al., 2015; Ivanov et al., 2017)). Utilizing multiple sources is one of the means to minimize the risks of supply disruption and to form a more competitive supply environment (Klassen \& Vereecke, 2012)). For instance, the firm is able to replace one halal source if the raw material quality were contaminated with forbidden elements. Moreover, utilization of halal logistics service providers such as halal warehouses may secure the firms' raw material from contaminated by the prohibited element (Tieman et al., 2013; Zailani et al., 2018). However, cost of the supplier's investment in the finished goods inventory will often be passed to the purchasing firm in the form of a higher price (Teng et al., 2016). The analysis also indicated price/cost risk, quality risk, and delivery risk significantly increase traceability-based management efforts. The more increase in halal supply risk, the more agencies will increase their traceability management efforts. The advantages of traceability management can channel the information related to halal standards allowing food manufacturers or consumers to verify halal products and secure the specification of the halal requirement (Shafii \& Khadijah, 2012). To ensure the halalness of the final products is an important issue in halal principles whereby the origin of the source of raw materials must be halal. By obtaining information from halal authority allows the agency to get information about the product (Ab Talib \& Chin, 2018) such as the name of suppliers who has the halal certification. The summary of the research hypotheses is shown in Table 10.

Table 10

Summary of hypotheses testing

\begin{tabular}{|c|c|c|}
\hline No. & Research hypotheses & Results \\
\hline 1 & Price \& cost risk significantly increases behavior-based management efforts. & Not supported \\
\hline 2 & Quality risk significantly increases behavior-based management efforts. & Supported \\
\hline 3 & Delivery risk significantly increases behavior-based management efforts. & Supported \\
\hline 4 & Price \& cost risk significantly increases buffer-based management efforts. & Supported \\
\hline 5 & Quality risk significantly increases buffer-based management efforts. & Supported \\
\hline 6 & Delivery risk significantly increases buffer-based management efforts. & Supported \\
\hline 7 & Price \& cost risk significantly increases traceability-based management efforts. & Supported \\
\hline 8 & Quality risk significantly increases traceability-based management efforts. & Supported \\
\hline 9 & Delivery risk significantly increases traceability-based management efforts. & Supported \\
\hline
\end{tabular}




\section{Conclusion and Implication of the Study}

The study has highlighted the gaps of literature in types of halal supply risk and mitigation strategy efforts and used agency theory to examine the agency uncertainties and mitigation approaches within food manufacturers. The study has shown that quality risk, delivery risk, and price/cost risk was an agency uncertainty in halal supply-side in food manufacturer. The study also has shown, behavior- and buffer-oriented efforts are able to cope with and manage many of the uncertainties present within the supply-side. Moreover, traceability-based management efforts also can assist the agency to manage the supply-side uncertainties. With respect to the practical implications, the firms suggest that investing more in buffer-oriented so as to mitigate the agency uncertainties. The adoption of this effort significantly contributed to all halal supply risk types in the supply chain rather than behavior-based efforts. However, the firms will face lot of costs (financial) to adopt to the buffer-oriented efforts.

\section{Acknowledgment}

This work was sponsored by Universiti Teknikal Malaysia Melaka (UTeM) Zamalah Scheme.

\section{References}

Ab Talib, M. S., \& Chin, T. A. (2018). Halal food standard implementation: are Malaysian firms proactive or reactive? British Food Journal, 120(6), 1330-1343.

Ab Talib, M. S., Hamid, A. B. A., \& Zulfakar, M. H. (2015). Halal supply chain critical success factors: A literature review. Journal of Islamic Marketing, 6(1), 44-71.

Abd Rahman, A., Singhry, H. B., Hanafiah, M. H., \& Abdul, M. (2017). Influence of perceived benefits and traceability system on the readiness for Halal Assurance System implementation among food manufacturers. Food Control, 73, $1318-1326$.

Ali, M. H., Tan, K. H., \& Ismail, M. D. (2017). A supply chain integrity framework for halal food. British Food Journal, 119(1), 20-38.

Alikhani, R., Torabi, S. A., \& Altay, N. (2019). Strategic supplier selection under sustainability and risk criteria. International Journal of Production Economics, 208, 69-82.

Awang, Z., Afthanorhan, A., \& Mamat, M. (2016). The Likert scale analysis using parametric based Structural Equation Modeling (SEM). Computational Methods in Social Sciences, 4(1), 13-21. https://doi.org/10.5281/zenodo.1299429

Bellmann, C., \& Hepburn, J. (2017). The decline of commodity prices and global agricultural trade negotiations: A game changer? International Development Policy| Revue Internationale de Politique de Développement, 8(8.1).

Cheng, T. C. E., Yip, F. K., \& Yeung, A. C. L. (2012). Supply risk management via guanxi in the Chinese business context: The buyer's perspective. International Journal of Production Economics, 139(1), 3-13.

Cleff, T. (2019). Factor analysis. In Applied Statistics and Multivariate Data Analysis for Business and Economics (pp. 433-446). Springer. https://doi.org/10.1007/978-3-030-17767-6_13

Diabat, A., Govindan, K., \& Panicker, V. V. (2012). Supply chain risk management and its mitigation in a food industry. International Journal of Production Research, 50(11), 3039-3050.

Dobni, C. B. (2008). Measuring innovation culture in organizations: The development of a generalized innovation culture construct using exploratory factor analysis. European Journal of Innovation Management, 11(4), 539-559.

Duan, Y., Miao, M., Wang, R., Fu, Z., \& Xu, M. (2017). A framework for the successful implementation of food traceability systems in China. Information Society, 33(4), 226-242.

Eisenhardt, K. M. (1989). Agency theory: an assessment and review. In Academy of Management Review (Vol. 14, Issue 1, pp. 57-74).

Fayezi, S., O'loughlin, A., \& Zutshi, A. (2012). Agency theory and supply chain management: a structured literature review. Supply Chain Management: An International Journal, 17(5), 556-570.

Fayezi, S., O’loughlin, A., Zutshi, A., Sohal, A., \& Das, A. (2019). What impacts do behaviour-based and buffer-based management mechanisms have on enterprise agility? Journal of Manufacturing Technology Management, 31(1), 169192.

Frazer, L., \& Lawley, M. (2001). Questionnaire design and administration: a practical guide. Wiley.

Fujiwara, T., \& Ismail, R. M. (2018). Supplier management system in halal food supply chain: A case study approach. International Journal of Supply Chain Management, 7(3), 216-220.

Gandhi, S. J., SchoolGorod, A., \& Sauser, B. (2012). Prioritization of outsourcing risks from a systemic perspective. Strategic Outsourcing: An International Journal, 5(1), 39-71.

Ghadge, A., Dani, S., Ojha, R., \& Caldwell, N. (2017). Using risk sharing contracts for supply chain risk mitigation: A buyer-supplier power and dependence perspective. Computers \& Industrial Engineering, 103, 262-270.

Gouda, S. K., \& Saranga, H. (2018). Sustainable supply chains for supply chain sustainability: impact of sustainability efforts on supply chain risk. International Journal of Production Research, 56(17), 5820-5835.

Hair, J. F., Black, W. C., Babin, B. J., Anderson, R. E., \& Tatham, R. L. (2009). Multivariate Data Analysis. Pearson.

Hair, J. F., Gabriel, M. L. D. S., Silva, D. da, \& Junior, S. B. (2019). Development and validation of attitudes measurement scales: fundamental and practical aspects and validation. RAUSP Management Journal. https://doi.org/10.1108/RAUSP-05-2019-0098

Hair, J. F., WC, B., BJ, B., \& RE, A. (2010). Multivariate data analysis, a global perspective. Pearson. 
Handayani, D. I., Prihatiningsih, T., Haryono, \& Prihatiningsih, T. (2019). Application of grey theory method for halal food risk assessment based on the traceability system in food supply chain. Advances in Intelligent Systems Research, 173, 426-434.

Henson, R. K., \& Roberts, J. K. (2006). Use of Exploratory Factor Analysis in Published Research Common Errors and Some Comment on Improved Practice. Educational and Psychological Measurement, 66(3), 393-416.

Ho, W., Zheng, T., Yildiz, H., \& Talluri, S. (2015). Supply chain risk management: A literature review. International Journal of Production Research, 53(16), 5031-5069.

Hosseini, S. M. P., Mirzaei, M., \& Iranmanesh, M. (2019). Determinants of Muslims' willingness to pay for halal certified food: Does religious commitment act as a moderator in the relationships? Journal of Islamic Marketing. https://doi.org/10.1108/JIMA-02-2018-0043

Ivanov, D., Dolgui, A., Sokolov, B., \& Ivanova, M. (2017). Literature review on disruption recovery in the supply chain. International Journal of Production Research, 55(20), 6158-6174.

Khan, Khan, M. I., Haleem, A., \& Jami, A. R. (2019). Prioritising the risks in halal food supply chain: an MCDM approach. Journal of Islamic Marketing. https://doi.org/10.1108/JIMA-10-2018-0206

Khan, S., Haleem, A., Khan, M. I., Abidi, M. H., \& Al-Ahmari, A. (2018). Implementing traceability systems in specific supply chain management (SCM) through critical success factors (CSFs). Sustainability, 10(1), 1-26.

Klassen, R. D., \& Vereecke, A. (2012). Social issues in supply chains: Capabilities link responsibility, risk (opportunity), and performance. International Journal of Production Economics, 140(1), 103-115.

Kristina, S., \& Wijaya, B. M. (2017). Risk management for food and beverage industry using Australia/New Zealand 4360 Standard. IOP Conference Series: Materials Science and Engineering, 277(1), 1-11.

Lynn, M. R. (1986). Determination and quantification of content validity. Nursing Research, 35(6), 382-385.

Manuj, I., \& Mentzer, J. T. (2008). Global supply chain risk management. Journal of Business Logistics, 29(1), 133-155.

Mat Aris, A. I., \& Soon, J. M. (2014). Investigation of Traceability and Recall Plans of Food Processing Plants and Small and Medium Enterprises in Kelantan, Malaysia. Journal of Food Processing, 2014, 1-10.

Mohamed, Y. H., Rahim, A. R. A., Ma'ram, A. B., \& Hamza, M. G. (2016). Halal traceability in enhancing halal integrity for food industry in Malaysia - A review. International Research Journal of Engineering and Technology, 3(3), 68-74.

Moretti, E. de A., Anholon, R., Rampasso, I. S., Silva, D., Santa-Eulalia, L. A., \& Ignácio, P. S. de A. (2019). Main difficulties during RFID implementation: an exploratory factor analysis approach. Technology Analysis and Strategic Management, 31(8), 943-956.

Nunnally, J. C., \& Bernstein, I. H. (1994). Psychometric theory (3rd ed.). McGraw-Hill.

Pett, M. A., Lackey, N. R. (Nancy R., \& Sullivan, J. J. (2003). Making sense of factor analysis : the use of factor analysis for instrument development in health care research. Sage Pub.

Prakash, S., Soni, G., Pal, A., Rathore, S., \& Singh, S. (2017). Risk analysis and mitigation for perishable food supply chain: a case of dairy industry. Benchmarking: An International Journal, 24(1), 2-23.

Radzi, R. M., Saidon, I. M., \& Ghani, N. A. (2017). Risk mitigating strategies in the food supply chain by Japanese food companies in Malaysia. International Journal of Management and Applied Science, 3(1), 89-93.

Rathore, R., Thakkar, J. J., \& Jha, J. K. (2017). A quantitative risk assessment methodology and evaluation of food supply chain. The International Journal of Logistics Management, 28(4), 1272-1293.

Shafii, Z., \& Khadijah, W. M. N. W. S. (2012). Halal traceability framework for halal food production. World Applied Sciences Journal, 17, 1-5.

Shafiq, A., Johnson, P. F., Klassen, R. D., \& Awaysheh, A. (2017). Exploring the implications of supply risk on sustainability performance. International Journal of Operations \& Production Management, 37(10), 1387-1407.

Spekman, R. E., \& Davis, E. W. (2004). Risky business: expanding the discussion on risk and the extended enterprise. International Journal of Physical Distribution \& Logistics Management, 34(5), 414-433.

Srinivasan, M., Mukherjee, D., \& Gaur, A. S. (2011). Buyer-supplier partnership quality and supply chain performance: Moderating role of risks, and environmental uncertainty. European Management Journal, 29(4), 260-271.

Supian, K. (2018). Cross-contamination in processing, packaging, storage, and transport in halal supply chain. In Preparation and Processing of Religious and Cultural Foods (pp. 309-321).

Teng, J. T., Cárdenas-Barrón, L. E., Chang, H. J., Wu, J., \& Hu, Y. (2016). Inventory lot-size policies for deteriorating items with expiration dates and advance payments. Applied Mathematical Modelling, 40(19-20), 8605-8616.

Tieman, M. (2019). Branding halal: a delicate balance. Islam and Civilisational Renewal (ICR), 10(2), $283-287$.

Tieman, M., Ghazali, M. C., \& van der Vorst, J. G. A. J. (2013). Consumer perception on halal meat logistics. British Food Journal, 115(8), 1112-1129.

Uyanık, G. K., \& Güler, N. (2013). A study on multiple linear regression analysis. Procedia-Social and Behavioral Sciences, $106,234-240$.

Whipple, J. M., \& Roh, J. (2010). Agency theory and quality fade in buyer-supplier relationships. The International Journal of Logistics Management, 21(3), 338-352.

Yaacob, T. Z., Rahman, F. A., \& Jaafar, H. S. (2018). Risk Categories in halal food transportation: a preliminary findings. International Journal of Supply Chain Management, 7(6), 453-461.

Yoon, J., Talluri, S., Yildiz, H., \& Ho, W. (2017). Models for supplier selection and risk mitigation : a holistic approach. International Journal of Production Research, 56(10), 3636-3661.

Zailani, S., Arrifin, Z., Wahid, N. A., Othman, R., \& Fernando, Y. (2010). Halal traceability and halal tracking systems in strengthening halal food supply chain for food industry in Malaysia (a review). Journal of Food Technology, 8(3), 74- 
81.

Zailani, S., Jafarzadeh, S., Iranmanesh, M., Nikbin, D., \& Selim, N. I. I. (2018). Halal logistics service quality: conceptual model and empirical evidence. British Food Journal, 120(11), 2599-2614.

Zamanzadeh, V., Ghahramanian, A., Rassouli, M., Abbaszadeh, A., Alavi-Majd, H., \& Nikanfar, A.-R. (2015). Design and Implementation Content Validity Study: Development of an instrument for measuring Patient-Centered Communication. Journal of Caring Sciences, 4(2), 165-178.

Zhao, J., Chen, A., You, X., Xu, Z., Zhao, Y., He, W., Zhao, L., \& Yang, S. (2018). A panel of SNP markers for meat traceability of Halal beef in the Chinese market. Food Control, 87, 94-99.

Zsidisin, G. A., \& Ellram, L. M. (2003). An Agency Theory Investigation of Supply Risk Management. Journal of Supply Chain Management, 39(2), 15-27.

Zsidisin, G. A., Petkova, B., Saunders, L. W., \& Bisseling, M. (2016). Identifying and managing supply quality risk. International Journal of Logistics Management, 27(3), 908-930. https://doi.org/10.1108/IJLM-02-2015-0043

$\mathrm{Zu}, \mathrm{X}$., \& Kaynak, H. (2012). An agency theory perspective on supply chain quality management. International Journal of Operations \& Production Management, 32(4), 423-446.

\section{Appendices A}

Halal food supply risk

\begin{tabular}{|c|c|c|c|c|c|c|c|c|c|c|c|}
\hline \multicolumn{12}{|c|}{ Please use the scale below to indicate the extent to which you agree or disagree with the following statements: } \\
\hline \multirow{3}{*}{ No. } & \multicolumn{11}{|c|}{ Price and cost risks } \\
\hline & \multirow[t]{2}{*}{ Items } & \multicolumn{5}{|c|}{$\begin{array}{r}1=\text { Strongly } \\
\text { disagree }\end{array}$} & \multicolumn{5}{|c|}{$\begin{array}{l}10=\text { strongly } \\
\text { agree }\end{array}$} \\
\hline & & 1 & 2 & 3 & 4 & 5 & 6 & 7 & 8 & 9 & 10 \\
\hline 1. & $\begin{array}{l}\text { Inability of a supplier to offer a competitive price for halal } \\
\text { products }\end{array}$ & & & & & & & & & & \\
\hline 2. & $\begin{array}{l}\text { Inconsistent price for halal products (e.g.: commodity price and } \\
\text { foreign exchange). }\end{array}$ & & & & & & & & & & \\
\hline 3. & Procurement of halal raw material increases costs. & & & & & & & & & & \\
\hline \multirow{3}{*}{ No. } & \multicolumn{11}{|l|}{$\begin{array}{ll} & \text { Quality risks } \\
\end{array}$} \\
\hline & \multirow[t]{2}{*}{ Items } & \multicolumn{5}{|c|}{$\begin{array}{r}1=\text { Strongly } \\
\text { disagree }\end{array}$} & \multicolumn{4}{|c|}{$\begin{array}{l}10=\text { strongly } \\
\text { agree }\end{array}$} & \\
\hline & & 1 & 2 & 3 & 4 & 5 & 6 & 7 & 8 & 9 & 10 \\
\hline 1. & $\begin{array}{l}\text { Quality problems with materials delivered not meet the halal } \\
\text { standard. }\end{array}$ & & & & & & & & & & \\
\hline 2. & $\begin{array}{l}\text { Supplier fails to adhere to specified food quality standards of } \\
\text { halal. }\end{array}$ & & & & & & & & & & \\
\hline 3. & Products are contaminated by unclean sources (najis) things. & & & & & & & & & & \\
\hline 4. & $\begin{array}{l}\text { Product is contaminated with haram sources (e.g.: pork or } \\
\text { alcohol). }\end{array}$ & & & & & & & & & & \\
\hline 5. & Supplier fails to maintain the wholesomeness of the product. & & & & & & & & & & \\
\hline 6. & Supplier uses illegal additives in the product supplied. & & & & & & & & & & \\
\hline 7. & Contains the forbidden or dirty component in the ingredients. & & & & & & & & & & \\
\hline 8. & $\begin{array}{l}\text { Dishonesty of the representatives liable for controlling the raw } \\
\text { materials. }\end{array}$ & & & & & & & & & & \\
\hline \multirow{3}{*}{ No. } & \multicolumn{11}{|l|}{$\begin{array}{ll} & \text { Delivery risks } \\
\end{array}$} \\
\hline & \multirow[t]{2}{*}{ Items } & \multicolumn{5}{|c|}{$\begin{array}{r}\text { I } \\
\text { Strongly } \\
\text { disagree }\end{array}$} & \multirow{2}{*}{\multicolumn{4}{|c|}{$\begin{array}{l}10=\text { strongly } \\
\text { agree }\end{array}$}} & \\
\hline & & 1 & 2 & 3 & 4 & 5 & & & & 9 & 10 \\
\hline 1. & Supplier fails to segregate allocation for halal products. & & & & & & & & & & \\
\hline 2. & Products are at contaminated by source of haram during delivery. & & & & & & & & & & \\
\hline 3. & Changes in transportation. & & & & & & & & & & \\
\hline 4. & Poor packaging and preservation. & & & & & & & & & & \\
\hline 5. & Tracking and tracing challenges of products. & & & & & & & & & & \\
\hline 6. & Goods received from suppliers are not in good condition. & & & & & & & & & & \\
\hline 7. & $\begin{array}{l}\text { Goods received from suppliers do not meet the specifications } \\
\text { requested. }\end{array}$ & & & & & & & & & & \\
\hline
\end{tabular}


Mitigation strategy

\begin{tabular}{|c|c|c|c|c|c|c|c|c|c|c|c|}
\hline \multirow{4}{*}{ No. } & dica & & & & & & & & & & \\
\hline & \multicolumn{11}{|c|}{ Behaviour-based management } \\
\hline & \multirow[t]{2}{*}{ Items } & \multicolumn{5}{|c|}{ 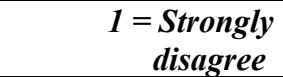 } & \multicolumn{5}{|c|}{$\begin{array}{l}10=\text { strongly } \\
\text { agree }\end{array}$} \\
\hline & & 1 & 2 & 3 & 4 & 5 & 6 & 7 & 8 & 9 & 10 \\
\hline 1. & $\begin{array}{l}\text { Our firm believes the information provided by the supplier (e.g.: } \\
\text { halal source of ingredients). }\end{array}$ & & & & & & & & & & \\
\hline 2. & Our supplier is genuinely concerned about halal integrity. & & & & & & & & & & \\
\hline 3. & Our supplier is trustworthy. & & & & & & & & & & \\
\hline 4. & Our firms' personnel frequently visit our supplier place of business. & & & & & & & & & & \\
\hline 5. & Our firm ensured the supplier is certified by halal standards. & & & & & & & & & & \\
\hline 6. & $\begin{array}{l}\text { Our firm implements a halal quality management program with the } \\
\text { supplier. }\end{array}$ & & & & & & & & & & \\
\hline 7. & $\begin{array}{l}\text { Our firm asses compliance and effectiveness of the suppliers' halal } \\
\text { quality system. }\end{array}$ & & & & & & & & & & \\
\hline 8. & $\begin{array}{l}\text { Our firm has a long-term, planned and strategic effort to improve } \\
\text { supplier capabilities in halal quality assurance and improvement. }\end{array}$ & & & & & & & & & & \\
\hline \multirow{3}{*}{ No. } & \multicolumn{11}{|l|}{ Buffer-based management } \\
\hline & \multirow[t]{2}{*}{ Items } & \multicolumn{5}{|c|}{$\begin{array}{r}1=\text { Strongly } \\
\text { disagree }\end{array}$} & \multicolumn{5}{|c|}{$\begin{array}{l}10=\text { strongly } \\
\text { agree }\end{array}$} \\
\hline & & 1 & 2 & 3 & 4 & 5 & 6 & 7 & 8 & 9 & 10 \\
\hline 1. & $\begin{array}{l}\text { Our firm has multiple halal supply sources for most purchased } \\
\text { items. }\end{array}$ & & & & & & & & & & \\
\hline 2. & $\begin{array}{l}\text { Our firm is able to replace one halal supply source with another at a } \\
\text { low cost. }\end{array}$ & & & & & & & & & & \\
\hline 3. & $\begin{array}{l}\text { Our firm is able to replace one halal supply source with another in a } \\
\text { short time. }\end{array}$ & & & & & & & & & & \\
\hline 4. & $\begin{array}{l}\text { Our firm has multiple halal production facilities that are located at } \\
\text { different sites. }\end{array}$ & & & & & & & & & & \\
\hline 5. & Most employees are certified in handling halal production. & & & & & & & & & & \\
\hline 6. & $\begin{array}{l}\text { Our supplier has access to different modes of halal transportation to } \\
\text { deliver products. }\end{array}$ & & & & & & & & & & \\
\hline 7. & Our supplier is able to change halal delivery modes at low cost. & & & & & & & & & & \\
\hline \multirow{3}{*}{ No. } & \multicolumn{11}{|l|}{ Traceability-based management } \\
\hline & \multirow[t]{2}{*}{ Items } & \multicolumn{5}{|c|}{$\begin{array}{r}1=\begin{array}{c}\text { Strongly } \\
\text { disagree }\end{array} \\
\end{array}$} & \multicolumn{5}{|c|}{$\begin{array}{l}10=\text { strongly } \\
\text { agree }\end{array}$} \\
\hline & & 1 & 2 & 3 & 4 & 5 & 6 & 7 & 8 & 9 & 10 \\
\hline 1. & $\begin{array}{l}\text { The authenticity of traceability information on halal suppliers (e.g.: } \\
\text { expiry date of halal certification). }\end{array}$ & & & & & & & & & & \\
\hline 2. & $\begin{array}{l}\text { Ability traces the quality of the halal product (e.g.: expiry of } \\
\text { products, freshness, etc.). }\end{array}$ & & & & & & & & & & \\
\hline 3. & Our firm has a mechanism and tools to provide timely info. & & & & & & & & & & \\
\hline 4. & $\begin{array}{l}\text { Ability to identify whether the product was dispatched or storage } \\
\text { accordingly based on halal standards. }\end{array}$ & & & & & & & & & & \\
\hline 5. & Our firm has transporter info (e.g.: transportation certified by halal). & & & & & & & & & & \\
\hline 6. & $\begin{array}{l}\text { Our firm provides traceability training to the employee (e.g.: halal } \\
\text { awareness). }\end{array}$ & & & & & & & & & & \\
\hline
\end{tabular}


(C) 2021 by the authors; licensee Growing Science, Canada. This is an open access article distributed under the terms and conditions of the Creative Commons Attribution (CC-BY) license (http://creativecommons.org/licenses/by/4.0/). 